\title{
Co-gasification characteristics of pine bark biomass and Bangladeshi bituminous coal using an entrained flow gasifier
}

\author{
M. Shahabuddin ${ }^{1}$ and Sankar Bhattacharya ${ }^{1}$ \\ ${ }^{1}$ Monash University
}

April 28, 2020

\begin{abstract}
Co-gasification of coal and renewable biomass is a promising technique to reduce greenhouse gas emission from coal gasification alone. The co-gasification performance of pine bark (PB) biomass and Bangladeshi bituminous coal (BBC) have been assessed using a high-temperature entrained flow gasifier under $\mathrm{CO} 2$ atmosphere. Results show that increasing biomass concentration increases the carbon conversion, syngas quality and cold gas efficiency (CGE), while reduces emission. Using $20 \% \mathrm{CO} 2$ as the reactant gas, an addition of $20 \%$ biomass with coal increased the carbon conversion by $21.5,10.6$ and $4.5 \%$-point at temperatures of 1000,1200 and $1400{ }^{\circ} \mathrm{C}$ compared to that of coal respectively. Increasing biomass in the blend from $20 \%$ to $80 \%$ increased the yield of $\mathrm{CO}$ by $36 \%, 21 \%$ and $11 \%$ with increasing temperature, while the concentration of $\mathrm{H} 2$ remained nearly constant. Also, the CGE, fragmentation index and alkali and alkaline earth minerals in ash were increased with increasing biomass ratio.
\end{abstract}

\section{Hosted file}

Manuscript .docx available at https://authorea.com/users/309215/articles/440456-co-gasificationcharacteristics-of-pine-bark-biomass-and-bangladeshi-bituminous-coal-using-an-entrained-flowgasifier 